\title{
Soluble Toll-Like Receptor 4 Impairs the Interaction of Shiga Toxin 2a with Human Serum Amyloid P Component
}

\author{
Maurizio Brigotti ${ }^{1, *}$, Valentina Arfilli ${ }^{1}$, Domenica Carnicelli ${ }^{1}{ }^{(D}$, Francesca Ricci ${ }^{2}{ }^{\circledR}$, \\ Pier Luigi Tazzari ${ }^{2}$, Gianluigi Ardissino ${ }^{3}$, Gaia Scavia ${ }^{4}$, Stefano Morabito ${ }^{4}$ and Xiaohua He ${ }^{5, *}$ \\ 1 Department of Experimental, Diagnostic and Specialty Medicine, University of Bologna, \\ Via San Giacomo 14, 40126 Bologna, Italy; arfilli.f@libero.it (V.A.); domenica.carnicelli@unibo.it (D.C.) \\ 2 Immunohematology and Transfusion Center, S. Orsola-Malpighi Hospital, Via Massarenti 9, 40138 Bologna, \\ Italy; francesca.ricci@aosp.bo.it (F.R.); pierluigi.tazzari@aosp.bo.it (P.L.T.) \\ 3 Center for HUS Control, Prevention and Management, Fondazione IRCCS Ca'Granda Ospedale Maggiore \\ Policlinico, Via Commenda 9, 20122 Milano, Italy; ardissino@italkid.org \\ 4 European Reference Laboratory for Escherichia coli, Istituto Superiore di Sanità, 00161 Rome, Italy; \\ gaia.scavia@iss.it (G.S.); stefano.morabito@iss.it (S.M.) \\ 5 Western Regional Research Center, U.S. Department of Agriculture, Agricultural Research Service, \\ 800 Buchanan Street, Albany, CA 94710, USA \\ * Correspondence: maurizio.brigotti@unibo.it (M.B.); xiaohua.he@ars.usda.gov (X.H.); \\ Tel.: +39-051-209-4716 (M.B.); +1-510-559-5823 (X.H.)
}

Received: 11 August 2018; Accepted: 14 September 2018; Published: 18 September 2018

\begin{abstract}
Shiga toxin 2a (Stx2a) is the main virulence factor produced by pathogenic Escherichia coli strains (Stx-producing E. coli, STEC) responsible for hemorrhagic colitis and the life-threatening sequela hemolytic uremic syndrome in children. The toxin released in the intestine by STEC targets the globotriaosylceramide receptor (Gb3Cer) present on the endothelial cells of the brain and the kidney after a transient blood phase during which Stx2a interacts with blood components, such as neutrophils, which, conversely, recognize Stx through Toll-like receptor 4 (TLR4). Among non-cellular blood constituents, human amyloid P component (HuSAP) is considered a negative modulating factor that specifically binds Stx2a and impairs its toxic action. Here, we show that the soluble extracellular domain of TLR4 inhibits the binding of Stx2a to neutrophils, assessed by indirect flow cytometric analysis. Moreover, by using human sensitive Gb3Cer-expressing cells (Raji cells) we found that the complex Stx2a/soluble TLR4 escaped from capture by HuSAP allowing the toxin to target and damage human cells, as assayed by measuring translation inhibition, the typical Stx-induced functional impairment. Thus, soluble TLR4 stood out as a positive modulating factor for Stx2a. In the paper, these findings have been discussed in the context of the pathogenesis of hemolytic uremic syndrome.
\end{abstract}

Keywords: hemolytic uremic syndrome; HuSAP; Shiga toxins; Toll-like receptor 4; decoy receptors

Key Contribution: Characterization of the interactions between Stx2a, soluble TLR4, and HuSAP.

\section{Introduction}

Shiga toxins (Stx) are powerful exotoxins involved in the pathogenesis of severe illnesses in children, such as hemorrhagic colitis and hemolytic uremic syndrome (HUS), related to infections by pathogenic Escherichia coli strains (Stx-producing E. coli, STEC) [1-3]. These bacteria colonize the human gut after ingestion of contaminated food and intimately adhere to the epithelial lining of the 
intestine where they release Stx [1-3]. Upon absorption into circulation, Stx bind to several circulating cells (precocious toxaemia) $[4,5]$ before targeting renal and cerebral endothelia which express the high-affinity receptor of the toxin, globotriaosylceramide (Gb3Cer) [6,7]. The latter event is the crucial point in the pathogenesis of HUS and occurs during advanced toxemia. Within cells, internalized Stx damage irreversibly ribosomes and DNA, causing the arrest of protein synthesis and the formation of apurinic sites in the nucleus [8,9]. As a consequence of the resulting endothelial injury/dysfunction, the formation of microthrombi occurs in renal glomeruli, causing the HUS triad, i.e. acute renal failure, mechanical damage of erythrocytes, and thrombocytopenia $[1,3]$.

During precocious toxemia the multiple interactions with blood components would foment or prevent the onset of HUS. Gb3Cer is also expressed by monocytes and platelets which are targeted by Stx (reviewed in [4]). The binding of Stx to monocytes induces the release of pro-inflammatory molecules involved in HUS [5], whereas the interaction of Stx with platelets has been suggested to be directly related to thrombocytopenia [10]. Conversely, human neutrophils can recognize Stx by means of the pattern recognition receptor Toll-like receptor 4 (TLR4), which is also present on the membrane of monocytes and platelets [11]. In contrast to the latter cells, human neutrophils interact with Stx only via-TLR4 since they do not express the repertoire of enzymes necessary to synthesize the neutral glycolipid Gb3Cer [12]. The role of neutrophils is controversial since these cells have been considered protective (toxin sponge effect) or causal (toxin delivery to target cells) in the pathogenesis of HUS [4].

Among Stx, the subtype Stx2a is the most dangerous toxin produced by STEC which confers HUS [13], in spite of the presence of a specific inhibitor of this toxin in human blood, named human serum amyloid P component (HuSAP). HuSAP is associated to high density lipoproteins [14] and is present in soluble form at constant concentrations as a pair of pentagonally structured subunits [15-18]. Even low concentrations of HuSAP inhibit the toxic activity of Stx2a for target cells in vitro and protect mice from lethal effects induced by this toxin $[15,18]$. The interaction of HuSAP with Stx2a is mediated both by the A subunit and the B pentamer [16], whereas the A chain or the B-pentamer of the toxins are mainly responsible for the interaction with TLR4 on neutrophil membrane $[19,20]$ or with Gb3Cer expressed by platelets, monocytes, and renal endothelial cells, respectively $[4,21]$.

Upon stimulation of TLRs by pathogen-associated molecular patterns (PAMPs), the cells of the innate immunity are activated $[22,23]$ and capable of releasing the decoy form of the corresponding TLR [24]. Soluble forms of TLR2 and TLR4 have been described in humans, which capture the specific stimulating PAMP hence reducing the responses of monocytes and neutrophils $[25,26]$. This mechanism is useful in preventing endotoxic shock by reducing the burden of pro-inflammatory cytokines released by monocyte/macrophages stimulated by the bacterial lipopolysaccharide via TLR4 (and the co-receptor MD2) [27-29]. The soluble decoy forms of TLR2 and TLR4 can be generated by (1) alternative mRNA splicing [30] or (2) conversion of the membrane receptor after endocytosis, followed by proteolysis in acidic compartments and subsequent exocytosis of the truncated form [25]. Recombinant soluble forms of the extracellular domain of TLR4 (70 kDa sTLR4) capable of dampening LPS-mediated TLR4-signaling have been obtained [28,29].

Since neutrophils and other innate immunity cells bind Stx through TLR4 and become activated after toxin stimulation, we have studied the effect of $70 \mathrm{kDa}$ sTLR4 on the biological activity of these toxins and on the Stx2a/HuSAP interactions.

\section{Results}

\subsection{Effect of the Soluble Recombinant Extracellular Domain of TLR4 on the Binding of Shiga Toxins to Neutrophils}

Human neutrophils from healthy donors were treated with $60 \mathrm{nM}$ Stx1a and Stx2a to reach full saturation of receptors [31]. The presence of 10-fold excess of $70 \mathrm{kDa}$ sTLR4 inhibited the interaction of both toxins with neutrophils (Figure 1), further confirming the identity of TLR4 as a Stx receptor. The presence of the co-receptor MD2 did not significantly modify the inhibitory power of the $70 \mathrm{kDa}$ 
sTLR4. The effect of $70 \mathrm{kDa}$ sTLR4 on the binding of Stx to neutrophils is specific since the decoy form of TLR2 [24] was not able to confer the protection.

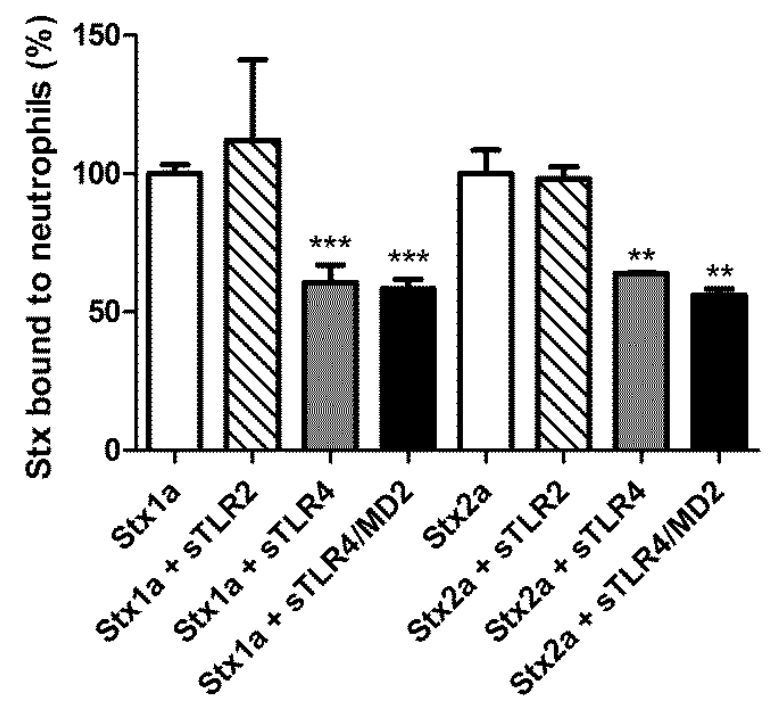

Figure 1. Inhibitory effect of the $70 \mathrm{kDa}$ sTLR4 on the binding of Stx1a and Stx2a to human neutrophils. Neutrophils isolated from healthy donors were treated with Stx $(60 \mathrm{nM})$ in the absence and in the presence of $600 \mathrm{nM}$ of $70 \mathrm{kDa}$ sTLR4, $70 \mathrm{kDa}$ sTLR4/MD2, or sTLR2. The extent of binding of Stx to neutrophils was measured by indirect flow cytometric analysis as described in Materials and Methods (Section 4.3). The mean channel values of fluorescence (MCVs) of neutrophils treated with Stx1a or Stx2a were (mean $\pm \mathrm{SD}, n=3$ ) $4.35 \pm 0.14$ or $3.90 \pm 0.33$, respectively. The data shown in the figure are expressed as binding percentages (mean $\pm \mathrm{SD}, n=3$, unpaired $t$-test) ${ }^{* * *} p<0.0001,{ }^{* *} p<0.001$.

\subsection{Effect of the Soluble Recombinant Extracellular Domain of TLR4 on the Activity of Shiga Toxin 2a on} Target Cells

To study the effect of $70 \mathrm{kDa}$ sTLR4 on the biological activity of Stx2a, we used Stx-sensitive human cells that express Gb3Cer, namely Raji cells. According to a previously described method [32], cells were treated for a short time $(3 \mathrm{~h}$ ) with Stx, and then cell translation was measured after the addition of a radioactive amino acid. The extent of protein synthesis inhibition with respect to control untreated cells was determined. The presence of $70 \mathrm{kDa}$ sTLR4 $(5 \mu \mathrm{g} / \mathrm{mL})$ or of the complex $70 \mathrm{kDa}$ sTLR4/MD2 $(5 \mu \mathrm{g} / \mathrm{mL})$ did not modify the $\mathrm{IC}_{50}$ of Stx2a on protein synthesis in Raji cells (Table 1), suggesting that a putative complex between Stx2a and cell-free soluble TLR4 is active in intoxicating target cells. Conversely, it is well known that Stx2a, but not Stx1a, acting on the same cellular model was greatly impaired by the presence of human serum containing HuSAP [32]. The effect of HuSAP on Stx2a is dramatic since even low concentration of purified HuSAP (10 nM) significantly impaired the cytotoxicity of Stx2a on Raji cells (Table 1). To verify if the binding of soluble TLR4 to Stx2a allows the toxin to escape from the capture by HuSAP, we pre-incubated Stx2a (0.5 nM) with a 1000 molar excess of both factors in different combinations and, after complexes formation, aliquots of the mixture were withdrawn and added to Raji cells to obtain a concentration of Stx2a (10 pM) approximately equal to its $\mathrm{IC}_{80}$, the inhibitor concentration that decreases translation by $80 \%$. The strong protection induced by HuSAP was significantly alleviated by pre-incubating Stx2a with 70 kDa sTLR4 (Figure 2). Moreover, the simultaneous addition of HuSAP, $70 \mathrm{kDa}$ STLR4, and Stx2a to the assay allowed similar effects (Figure 2). Thus, the soluble form of TLR4 may impair HuSAP protection by creating physical hindrance for binding between HuSAP and Stx2a. It should be noted that if the opposite experiment was performed, i.e. pre-incubation of the toxin with HuSAP and then addition of $70 \mathrm{kDa}$ sTLR4 to the assay, no action of the toxin was permitted. Hence, soluble TLR4 is not able to displace the toxin from the HuSAP/Stx2a complex. One can conclude that the simple release of soluble TLR4 in patients' sera after monocyte/neutrophil challenge induced by LPS or Stx would have no effect once the binding of 
HuSAP with Stx2a had occurred. On the other hand, soluble TLR4 could interfere with HuSAP binding to freshly entered Stx2a in blood stream from the intestine. Although these experiments allowed us to conceptualize the reciprocal relationship between Stx $2 \mathrm{a}$ and protective and/or inhibitory factors, they have been performed in conditions far from those observed in human sera. Thus, we calculated the $\mathrm{IC}_{50}$ of Stx2a on Raji cell translation in the presence of normal human serum. It was shown that simultaneous addition of Stx2a and high concentration of $70 \mathrm{kDa}$ sTLR4 $(10 \mathrm{nM})$ to Raji cells containing $10 \%$ human serum had no effect (Table 1 ) on $\mathrm{IC}_{50}$ compared with Raji cells without adding soluble TLR4. Conversely, the addition of Stx2a pre-incubated with $70 \mathrm{kDa}$ sTLR4 significantly decreased the $\mathrm{IC}_{50}$ (Table 1). Therefore, a substantial increase of Stx2a toxicity would be achieved if TLR4/Stx2a complex is formed before Stx2a interacts with HuSAP.

Table 1. Effects of the soluble extracellular domain of TLR4 or of HuSAP on the inhibition of translation induced by Stx2a in Raji cells.

\begin{tabular}{cccc}
\hline Additions & $\begin{array}{c}\text { IC }_{\mathbf{5 0}}{ }^{\text {a }} \text { Stx2a } \\
\text { Fold Increase }\end{array}$ & $\begin{array}{c}\text { IC }_{\mathbf{5 0}} \\
\text { Determination (r) }\end{array}$ & $\begin{array}{c}\text { Statistical } \\
\text { Significance }\end{array}$ \\
\hline None & 1 & -0.991 & - \\
$5 \mu \mathrm{g} / \mathrm{mL}$ sTLR4 $(70 \mathrm{nM})$ & 1 & -0.999 & n.s. \\
$5 \mu \mathrm{g} / \mathrm{mL} \mathrm{sTLR4/MD2}(55 \mathrm{nM})$ & 1 & -0.999 & n.s. \\
$0.25 \mu \mathrm{g} / \mathrm{mL}$ HuSAP $(1 \mathrm{nM})$ & 1.6 & -0.977 & n.s. \\
$2.50 \mu \mathrm{g} / \mathrm{mL} \mathrm{HuSAP}(10 \mathrm{nM})$ & 52.2 & -0.999 & $p<0.0001$ \\
$10 \%$ human serum & 20.7 & -0.992 & $p<0.0001$ \\
$10 \%$ human serum + sTLR4 $(10 \mathrm{nM})$ & 21.0 & -0.967 & $p>0.00001$ \\
$10 \%$ human serum + (Stx2a & $14.7 *$ & -0.999 & \\
pre-incubated with sTLR4) & & & \\
\hline
\end{tabular}

${ }^{a} \mathrm{IC}_{50}$ were calculated by the linear regression between fractional activity and the log of Stx2a concentrations. ${ }^{\mathrm{b}}$ The statistical significance of the differences between the intercepts of the straight lines obtained with the indicated additions with respect to Stx2a alone (none) are reported (n.s., not significant). * Significant difference between the intercepts of the straight lines obtained in the presence of $10 \%$ human serum with Stx2a and with Stx2a/ $70 \mathrm{kDa}$ sTLR4 complex $(p<0.05)$.

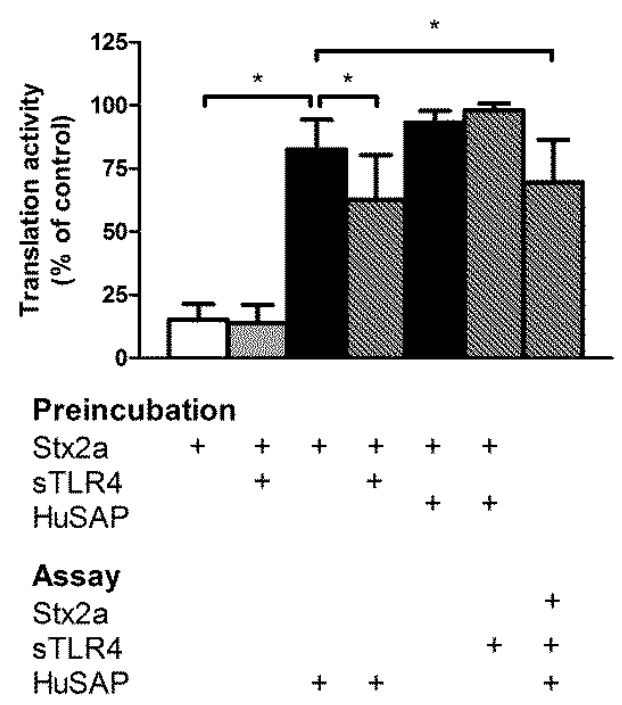

Figure 2. Effect of HuSAP and $70 \mathrm{kDa}$ sTLR4 on the inhibitory activity of Stx2a on Raji cell translation. Preincubation: Stx2a $(0.5 \mathrm{nM})$ was preincubated in the absence and in the presence of HuSAP $(0.5 \mu \mathrm{M})$ or $70 \mathrm{kDa}$ sTLR4 $(0.5 \mu \mathrm{M})$ in $22.5 \mu \mathrm{L}$ PBS for $10 \mathrm{~min}$ at $37^{\circ} \mathrm{C}$. After incubation, $10 \mu \mathrm{L}$ aliquots were withdrawn and added to Raji cells (final volume $500 \mu \mathrm{L}$ ) to reach the final concentrations $10 \mathrm{pM}$ Stx2a (IC 80 on Raji cell translation), $10 \mathrm{nM}$ HuSAP, and $10 \mathrm{nM} 70 \mathrm{kDa}$ sTLR4. Where indicated Stx2a $(10 \mathrm{pM}), \mathrm{HuSAP}(10 \mathrm{nM})$, and $70 \mathrm{kDa}$ sTLR4 $(10 \mathrm{nM})$ were directly added to the assay. The data are expressed as percentage activity (mean $\pm \mathrm{SD}$, two-tailed paired $t$-test, $n=4$ ), ${ }^{*} p<0.01$. + : addition of the indicated compounds. 


\section{Discussion}

In this paper the effects of the extracellular soluble domain of TLR4 on the biological activity of Stx and Stx interaction with blood components (neutrophils, HuSAP) involved in the pathogenesis of HUS have been investigated. The soluble form of TLR4 was found to impair neutrophil/Stx interactions. However, high concentrations of $70 \mathrm{kDa}$ sTLR4 were required to achieve this negative modulating function: $600 \mathrm{nM}(\sim 40 \mu \mathrm{g} / \mathrm{mL})$ when the receptors on neutrophils are $100 \%$ saturated (Figure 1) or $60 \mathrm{nM}(\sim 4 \mu \mathrm{g} / \mathrm{mL})$ when the receptors are $50 \%$ saturated (data not shown). These high concentrations of sTLR4 appear well beyond the capability of circulating monocytes or neutrophils because the maximal concentrations of the top mediators induced by Stx in these cells usually range from $\sim 1 \mathrm{ng} / \mathrm{mL}$ (CXCL8, neutrophils) to $\sim 30 \mathrm{ng} / \mathrm{mL}$ (CXCL8, monocytes) [5]. Moreover, $60 \mathrm{nM} 70 \mathrm{kDa}$ sTLR4 corresponds to $3.6 \times 10^{13}$ molecules per milliliter, while the average numbers of neutrophils and monocytes in a two-year-old child's blood are about $3.5 \times 10^{6}$ and $5 \times 10^{5}$ per milliliter [33], respectively, suggesting each cell has to release $1-7 \times 10^{7}$ sTLR4 molecules to reach the needed level, which is highly unlikely. Based on preliminary ELISA on sera from patients with STEC-induced HUS the concentration of the soluble form of TLR4 was nanogram per milliliter level (data not shown). Thus, the hypothesis that the soluble TLR4 would inhibit the binding of freshly entered Stx in blood from the gut to neutrophils seems unlikely during the natural course of STEC-infections.

Our results demonstrated that cell-free TLR4 protected Stx2a from capturing by HuSAP in blood that inhibits Stx2a interaction with Gb3Cer on target cells. Once a Stx2a/HuSAP complex is formed, soluble TLR4 is no longer able to displace HuSAP. Conversely, formation of Stx2a/70 kDa sTLR4 complex allows the toxin to bind Gb3Cer. According to calculation of the reciprocal interactions between these factors based on the physiological concentrations of HuSAP and on experiments with human serum as source of HuSAP, it is also unlikely that soluble TLR4 would be able to prevent the formation of the Stx2a/HuSAP complex in patients' blood.

A possible explanation for Stx2a forming complex with sTLR4 before interacting with HuSAP is that certain amounts of soluble TLR4 could be produced during the intestinal phase of STEC-infections by LPS- or Stx2a-stimulated macrophages resident in the lamina propria of the gut. In this case, the toxin would translocate through the intestinal barrier as Stx2a/sTLR4 complex.

Another attractive hypothesis is that detachment of Stx2a already bound with TLR4 in circulating cells would allow Stx2a to escape from HuSAP negative modulating effect. This could happen (1) after proteolytic processing of the membrane TLR4 originating macromolecular complexes Stx2a/sTLR4 or (2) considering Stx2a as a membrane component bound to TLR4 present on microvesicles released by activated circulating cells after toxin challenge. It is worth noting that one of the most recent hypotheses on the pathogenesis of STEC-induced HUS proposed that Stx-containing microvesicles released by circulating cells may be the main trigger. In this model, circulating cells represent a reservoir of toxins available for the follow-up intoxication of the renal target cells after their release. At a molecular level, the binding of the extracellular domain of TLR4 exposed on microvesicles to Stx2a could protect toxin from binding by HuSAP, hence favoring its toxicity for target endothelial cells. As shown in Figure 2 and Table 1, the toxicity of Stx2a rescued by soluble TLR4 is only partial, however, over a sufficiently long period of time, this toxicity could accumulate to a level high enough to cause diseases. The role of blood cell-derived Stx-containing microvesicles and the relevance of the soluble form of TLR4 in HUS needs to be further validated in studies on patients during the natural course of STEC-infections.

\section{Materials and Methods}

\subsection{Materials and Toxins}

Stx1a produced by E. coli C600 (H19J) and Stx2a produced by E. coli C600 (933W) were purified by receptor analog affinity chromatography, on globotriose-Fractogel (IsoSep, Lund, Sweden) [34] and on (Gala1-4Galb-O-spacer)-BSASepharose 4B (Glycorex, Lund, Sweden) [35], respectively, followed in both cases by a passage through ActiClean Etox columns (Sterogene Bioseparations, Carlsbad, CA, 
USA) to remove trace endotoxin contaminant. HuSAP was purchased from Sigma-Aldrich (St. Louis, MO, USA); 70 kDa sTLR4 (human recombinant extracellular domain of TLR4), 70 kDa sTLR4/MD2 complex, and recombinant human TLR2 were obtained by R\&D Systems (Minneapolis, MN, USA) and resuspended as described in the manufacturer's instructions.

\subsection{Experimental Binding of Shiga Toxins to Human Neutrophils}

Highly pure neutrophils (99.7\%) were isolated under endotoxin-low conditions from buffy coats of healthy donors after centrifugation over Ficoll-Paque, followed by dextran sedimentation, hypotonic lysis of contaminating erythrocytes, and removing of any eventual contaminating cells by using the EasySep human neutrophil enrichment kit (Stemcell Technologies, Vancouver, BC, Canada) [11,36]. Healthy donors gave their informed consent for the use of their blood samples in the experiments described in this paper. For binding experiments with purified Stx1a and Stx2a, Eppendorf tubes were precoated with PBS containing $1 \%$ endotoxin-low ( $\leq 1$ endotoxin unit/mg) BSA to avoid nonspecific loss of the toxins. Neutrophils $\left(5 \times 10^{5}\right)$ were incubated for $90 \mathrm{~min}$ at $37^{\circ} \mathrm{C}$ with $60 \mathrm{nM} \mathrm{Stx}$ in $250 \mu \mathrm{L}$ of the same buffer (PBS-BSA). After incubation, the cells were spun down at $200 \times g$ for 5 min and washed three times with $100 \mu \mathrm{L}$ incubation buffer at $37^{\circ} \mathrm{C}$. Stx bound to neutrophils were detected by flow cytometry as describe in the paragraph below.

\subsection{Detection of Shiga Toxins Bound to Neutrophils}

Stx bound to neutrophils were detected by flow cytometry, as reported in a specific methodological article in which all technical details were carefully described [31]. The assay was validated by comparing control subjects and HUS patients in a blinded manner [31] and by challenging Stx-positive neutrophils with a negative control antibody [37]. Briefly, untreated or Stx-treated neutrophils were incubated with mouse monoclonal antibodies (IgG) against Stx1a (Stx1-13C4, Toxin Technology, Sarasota, FL, USA) or Stx2a (Stx2-BB12, Toxin Technology, Sarasota, FL, USA) in the presence of human serum to saturate Fc receptors on leukocytes. After incubation with FITC-goat anti-mouse IgG, flow cytometric analysis was used to reveal the neutrophil-bound fluorescence, allowing a highly sensitive detection of both Stx. Cells were visualized by a cytogram that combined forward scatter versus $90^{\circ}$ side scatter, and fluorescence was analyzed by a cytogram that combined $90^{\circ}$ side scatter and fluorescence and by a single-fluorescence histogram. Neutrophils were checked by staining with $\mathrm{mAb}$ to Ags associated to granulocytes (FITC-CD16 and FITC-CD65, Beckman Coulter, Miami, FL, USA). The mean channel value of fluorescence (MCV) was chosen as an objective parameter to measure the extent of binding of Stx to neutrophils.

\subsection{Detection of the Functional Activity of Shiga Toxins in Whole Cells}

The rapid intoxication kinetic of human Gb3Cer-expressing Raji cells and their high sensitivity to Stx were exploited for the detection of the toxic activity of Stx2a by measuring the inhibition of translation [32]. Protein synthesis was measured after $3 \mathrm{~h}$ incubation with different concentrations of Stx $2 \mathrm{a}$ as the rate of incorporation of $\left[{ }^{3} \mathrm{H}\right]$ leucine into proteins during 60 min incubation in complete medium as described previously [32] in the absence or in the presence of pooled human serum from three healthy donors as source of HuSAP.

\subsection{Statistical Analysis}

Statistical analysis was performed with GraphPad Prism 5 software (GraphPad Software, La Jolla, CA, USA). Continuous variables were described through means and SD. Differences in continuous variables were tested with a $t$-test after controlling the normality of their distribution. Correlation between variables was assessed using the Pearson correlation coefficient. A $p$ value $<0.05$ was considered statistically significant. 
Author Contributions: Conceptualization and writing: M.B., G.A., G.S., S.M. and X.H.; Investigation: V.A., D.C., F.R. and P.L.T.; Data curation: V.A., D.C., F.R., P.L.T, M.B., G.A., G.S., S.M. and X.H.

Funding: This research was funded by University of Bologna (M.B.), Progetto ALICE ONLUS-Associazione per la lotta alla SEU (M.B).

Conflicts of Interest: The authors declare no conflict of interest. The funders had no role in the design of the study; in the collection, analyses, or interpretation of data; in the writing of the manuscript, or in the decision to publish the results.

\section{References}

1. Karch, H.; Tarr, P.I.; Bielaszewska, M. Enterohaemorrhagic Escherichia coli in human medicine. Int. J. Med. Microbiol. 2005, 295, 405-418. [CrossRef] [PubMed]

2. Mayer, C.L.; Leibowitz, C.S.; Kurosawa, S.; Stearns-Kurosawa, D.J. Shiga toxins and the pathophysiology of hemolytic uremic syndrome in humans and animals. Toxins 2012, 4, 1261-1287. [CrossRef] [PubMed]

3. Tarr, P.I.; Gordon, C.A.; Chandler, W.L. Shiga-toxin-producing Escherichia coli and haemolytic uraemic syndrome. Lancet 2005, 365, 1073-1086. [CrossRef]

4. Brigotti, M. The interactions of human neutrophils with Shiga toxins and related plant toxins: Danger or safety? Toxins 2012, 4, 157-190. [CrossRef] [PubMed]

5. Brigotti, M.; Carnicelli, D.; Arfilli, V.; Porcellini, E.; Galassi, E.; Valerii, M.C.; Spisni, E. Human monocytes stimulated by Shiga toxin 1a via globotriaosylceramide release proinflammatory molecules associated with hemolytic uremic syndrome. Int. J. Med. Microbiol. 2018. [CrossRef] [PubMed]

6. Legros, N.; Dusny, S.; Humpf, H.U.; Pohlentz, G.; Karch, H.; Muthing, J. Shiga toxin glycosphingolipid receptors and their lipid membrane ensemble in primary human blood-brain barrier endothelial cells. Glycobiology 2017, 27, 99-109. [CrossRef] [PubMed]

7. Legros, N.; Pohlentz, G.; Runde, J.; Dusny, S.; Humpf, H.U.; Karch, H.; Muthing, J. Colocalization of receptors for Shiga toxins with lipid rafts in primary human renal glomerular endothelial cells and influence of D-PDMP on synthesis and distribution of glycosphingolipid receptors. Glycobiology 2017, 27, 947-965. [CrossRef] [PubMed]

8. Brigotti, M.; Alfieri, R.; Sestili, P.; Bonelli, M.; Petronini, P.G.; Guidarelli, A.; Barbieri, L.; Stirpe, F.; Sperti, S. Damage to nuclear DNA induced by Shiga toxin 1 and ricin in human endothelial cells. FASEB J. 2002, 16, 365-372. [CrossRef] [PubMed]

9. Brigotti, M.; Carnicelli, D.; Ravanelli, E.; Vara, A.G.; Martinelli, C.; Alfieri, R.R.; Petronini, P.G.; Sestili, P. Molecular damage and induction of proinflammatory cytokines in human endothelial cells exposed to Shiga toxin 1, Shiga toxin 2, and alpha-sarcin. Infect. Immun. 2007, 75, 2201-2207. [CrossRef] [PubMed]

10. Karpman, D.; Papadopoulou, D.; Nilsson, K.; Sjogren, A.C.; Mikaelsson, C.; Lethagen, S. Platelet activation by Shiga toxin and circulatory factors as a pathogenetic mechanism in the hemolytic uremic syndrome. Blood 2001, 97, 3100-3108. [CrossRef] [PubMed]

11. Brigotti, M.; Carnicelli, D.; Arfilli, V.; Tamassia, N.; Borsetti, F.; Fabbri, E.; Tazzari, P.L.; Ricci, F.; Pagliaro, P.; Spisni, E.; et al. Identification of TLR4 as the receptor that recognizes Shiga toxins in human neutrophils. J. Immun. 2013, 191, 4748-4758. [CrossRef] [PubMed]

12. Macher, B.A.; Klock, J.C. Isolation and chemical characterization of neutral glycosphingolipids of human neutrophils. J. Biol. Chem. 1980, 255, 2092-2096. [PubMed]

13. Friedrich, A.W.; Bielaszewska, M.; Zhang, W.L.; Pulz, M.; Kuczius, T.; Ammon, A.; Karch, H. Escherichia coli harboring Shiga toxin 2 gene variants: Frequency and association with clinical symptoms. J. Infect. Dis. 2002, 185, 74-84. [CrossRef] [PubMed]

14. Caprioli, A.; Luzzi, I.; Seganti, L.; Marchetti, M.; Karmali, M.; Clarke, I.; Boyd, B. Frequency and nature of Verocytotoxin-2 (VT2) neutralizing activity (NA) in human and animal sera. In Recent Advances in Verocytotoxin-Producing Escherichia coli Infections; Karmali, M.A., Goglio, A.G., Eds.; Elsevier: Amsterdam, The Netherlands, 1994; Volume 1072, pp. 353-356.

15. Kimura, T.; Tani, S.; Matsumoto Yi, Y.; Takeda, T. Serum amyloid P component is the Shiga toxin 2-neutralizing factor in human blood. J. Biol. Chem. 2001, 276, 41576-41579. [CrossRef] [PubMed]

16. Marcato, P.; Vander Helm, K.; Mulvey, G.L.; Armstrong, G.D. Serum amyloid P component binding to Shiga toxin 2 requires both A subunit and B pentamer. Infect. Immun. 2003, 71, 6075-6078. [CrossRef] [PubMed] 
17. Skinner, M.; Cohen, A.S. Amyloid P component. Method. Enzymol. 1988, 163, 523-536.

18. Armstrong, G.D.; Mulvey, G.L.; Marcato, P.; Griener, T.P.; Kahan, M.C.; Tennent, G.A.; Sabin, C.A.; Chart, H.; Pepys, M.B. Human serum amyloid P component protects against Escherichia coli O157:H7 Shiga toxin 2 in vivo: Therapeutic implications for hemolytic-uremic syndrome. J. Infect. Dis. 2006, 193, 1120-1124. [CrossRef] [PubMed]

19. Arfilli, V.; Carnicelli, D.; Rocchi, L.; Ricci, F.; Pagliaro, P.; Tazzari, P.L.; Brigotti, M. Shiga toxin 1 and ricin A chain bind to human polymorphonuclear leucocytes through a common receptor. Biochem. J. 2010, 432, 173-180. [CrossRef] [PubMed]

20. Griener, T.P.; Mulvey, G.L.; Marcato, P.; Armstrong, G.D. Differential binding of Shiga toxin 2 to human and murine neutrophils. J. Med. Microbiol. 2007, 56, 1423-1430. [CrossRef] [PubMed]

21. Bauwens, A.; Betz, J.; Meisen, I.; Kemper, B.; Karch, H.; Muthing, J. Facing glycosphingolipid-Shiga toxin interaction: Dire straits for endothelial cells of the human vasculature. Cell Mol. Life Sci. 2013, 70, 425-457. [CrossRef] [PubMed]

22. Akira, S.; Uematsu, S.; Takeuchi, O. Pathogen recognition and innate immunity. Cell 2006, 124, $783-801$. [CrossRef] [PubMed]

23. Creagh, E.M.; O'Neill, L.A. TLRs, NLRs and RLRs: A trinity of pathogen sensors that co-operate in innate immunity. Trend. Immunol. 2006, 27, 352-357. [CrossRef] [PubMed]

24. Liew, F.Y.; Xu, D.; Brint, E.K.; O'Neill, L.A. Negative regulation of Toll-like receptor-mediated immune responses. Nat. Rev. Immunol. 2005, 5, 446-458. [CrossRef] [PubMed]

25. LeBouder, E.; Rey-Nores, J.E.; Rushmere, N.K.; Grigorov, M.; Lawn, S.D.; Affolter, M.; Griffin, G.E.; Ferrara, P.; Schiffrin, E.J.; Morgan, B.P.; et al. Soluble forms of toll-like receptor (TLR)2 capable of modulating TLR2 signaling are present in human plasma and breast milk. J. Immunol. 2003, 171, 6680-6689. [CrossRef] [PubMed]

26. Zunt, S.L.; Burton, L.V.; Goldblatt, L.I.; Dobbins, E.E.; Srinivasan, M. Soluble forms of Toll-like receptor 4 are present in human saliva and modulate tumour necrosis factor-alpha secretion by macrophage-like cells. Clin. Exp. Immunol. 2009, 156, 285-293. [CrossRef] [PubMed]

27. Iwami, K.I.; Matsuguchi, T.; Masuda, A.; Kikuchi, T.; Musikacharoen, T.; Yoshikai, Y. Cutting edge: Naturally occurring soluble form of mouse Toll-like receptor 4 inhibits lipopolysaccharide signaling. J. Immunol. 2000, 165, 6682-6686. [CrossRef] [PubMed]

28. Mitsuzawa, H.; Nishitani, C.; Hyakushima, N.; Shimizu, T.; Sano, H.; Matsushima, N.; Fukase, K.; Kuroki, Y. Recombinant soluble forms of extracellular TLR4 domain and MD-2 inhibit lipopolysaccharide binding on cell surface and dampen lipopolysaccharide-induced pulmonary inflammation in mice. J. Immunol. 2006, 177, 8133-8139. [CrossRef] [PubMed]

29. Hyakushima, N.; Mitsuzawa, H.; Nishitani, C.; Sano, H.; Kuronuma, K.; Konishi, M.; Himi, T.; Miyake, K.; Kuroki, Y. Interaction of soluble form of recombinant extracellular TLR4 domain with MD-2 enables lipopolysaccharide binding and attenuates TLR4-mediated signaling. J. Immunol. 2004, 173, 6949-6954. [CrossRef] [PubMed]

30. Jaresova, I.; Rozkova, D.; Spisek, R.; Janda, A.; Brazova, J.; Sediva, A. Kinetics of Toll-like receptor-4 splice variants expression in lipopolysaccharide-stimulated antigen presenting cells of healthy donors and patients with cystic fibrosis. Micro. Infect. 2007, 9, 1359-1367. [CrossRef] [PubMed]

31. Tazzari, P.L.; Ricci, F.; Carnicelli, D.; Caprioli, A.; Tozzi, A.E.; Rizzoni, G.; Conte, R.; Brigotti, M. Flow cytometry detection of Shiga toxins in the blood from children with hemolytic uremic syndrome. Cytometry $B$ Clin. Cytom. 2004, 61, 40-44. [CrossRef] [PubMed]

32. Arfilli, V.; Carnicelli, D.; Ardissino, G.; Torresani, E.; Scavia, G.; Brigotti, M. A rapid and sensitive method to measure the functional activity of Shiga toxins in human serum. Toxins 2015, 7, 4564-4576. [CrossRef] [PubMed]

33. Dallman, P.R. Rudolph's pediatrics, 16th ed.; Appleton-Century-Crofts: New York, NY, USA, 1977.

34. Ryd, M.; Alfredsson, H.; Blomberg, L.; Andersson, A.; Lindberg, A.A. Purification of Shiga toxin by alpha-D-galactose-(1-4)-beta-D-galactose-(1-4)-beta-D-glucose-(1-) receptor ligand-based chromatography. FEBS Lett. 1989, 258, 320-322. [CrossRef]

35. Matussek, A.; Lauber, J.; Bergau, A.; Hansen, W.; Rohde, M.; Dittmar, K.E.; Gunzer, M.; Mengel, M.; Gatzlaff, P.; Hartmann, M.; et al. Molecular and functional analysis of Shiga toxin-induced response patterns in human vascular endothelial cells. Blood 2003, 102, 1323-1332. [CrossRef] [PubMed] 
36. Brigotti, M.; Carnicelli, D.; Ravanelli, E.; Barbieri, S.; Ricci, F.; Bontadini, A.; Tozzi, A.E.; Scavia, G.; Caprioli, A.; Tazzari, P.L. Interactions between Shiga toxins and human polymorphonuclear leukocytes. J. Leukoc. Biol. 2008, 84, 1019-1027. [CrossRef] [PubMed]

37. Brigotti, M.; Caprioli, A.; Tozzi, A.E.; Tazzari, P.L.; Ricci, F.; Conte, R.; Carnicelli, D.; Procaccino, M.A.; Minelli, F.; Ferretti, A.V.; et al. Shiga toxins present in the gut and in the polymorphonuclear leukocytes circulating in the blood of children with hemolytic-uremic syndrome. J. Clin. Microbiol. 2006, 44, 313-317. [CrossRef] [PubMed]

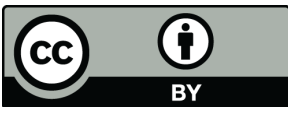

(C) 2018 by the authors. Licensee MDPI, Basel, Switzerland. This article is an open access article distributed under the terms and conditions of the Creative Commons Attribution (CC BY) license (http:/ / creativecommons.org/licenses/by/4.0/). 